\title{
HEALTH STATUS MEASUREMENT: A PERSPECTIVE ON CHANGE
}




\section{ECONOMIC ISSUES IN HEALTH CARE}

General editors

Professor Gavin Mooney

Department of Community Medicine

Westmead Hospital

Westmead, NSW 2145

Australia
Dr Alistair McGuire

Deparment of Economics

City University

Nottingham Square

London ECIV OHB

The Challenges of Medical Practice Variations

Edited by Tavs Folmer Andersen and Gavin Mooney (1990)

Competition in Health Care: Reforming the NHS

Edited by A.J. Culyer, Alan Maynard and John Posnett (1990)

Strategies for Health Care Finance in Developing Countries

By Guy Carrin with Marc Vereecke (1992)

Private Exchange and Public Interest

By John Forbes (1992)

Just Managing - Power and Culture in the NHS

By Stephen Harrison, David J. Hunter and Gordon Marnoch (1992)

Economics of Health Care Financing: The Visible Hand

By Cam Donaldson and Karen Gerard (1992)

Rationing and Rationality in the National Health Service

Edited by Stephen J. Frankel and R.R. West (1993)

Health Status Measurement: A Perspective on Change

By Richard G. Brooks (1995) 


\section{HEALTH STATUS MEASUREMENT: A PERSPECTIVE ON CHANGE}

\section{Richard G. Brooks}

Department of Economics

University of Strathclyde

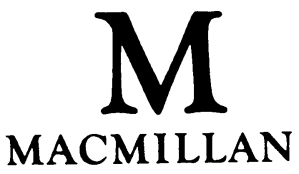


All rights reserved. No reproduction, copy or transmission of this publication may be made without written permission.

No paragraph of this publication may be reproduced, copied or transmitted save with written permission or in accordance with the provisions of the Copyright, Designs and Patents Act 1988, or under the terms of any licence permitting limited copying issued by the Copyright Licensing Agency, 90 Tottenham Court Road, London W1P 9HE.

Any person who does any unauthorised act in relation to this publication may be liable to criminal prosecution and civil claims for damages.

First published 1995 by

MACMILLAN PRESS LTD

Houndmills, Basingstoke, Hampshire RG21 2XS

and London

Companies and representatives

throughout the world

ISBN 978-0-333-52720-7

DOI 10.1007/978-1-349-23687-9

ISBN 978-1-349-23687-9 (eBook)

A catalogue record for this book is available

from the British Library.

$\begin{array}{cccccccccc}10 & 9 & 8 & 7 & 6 & 5 & 4 & 3 & 2 & 1 \\ 04 & 03 & 02 & 01 & 00 & 99 & 98 & 97 & 96 & 95\end{array}$

\section{Series Standing Order (Economic Issues in Health Care)}

If you would like to receive future titles in this series as they are published, you can make use of our standing order facility. To place a standing order please contact your bookseller or, in case of difficulty, write to us at the address below with your name and address and the name of the series. Please state with which title you wish to begin your standing order. (If you live outside the UK we may not have the rights for your area, in which case we will forward your order to the publisher concerned.)

Standing Order Service, Macmillan Distribution Ltd, Houndmills, Basingstoke, Hampshire, RG21 2XS, England 
In memory of my mother 


\section{Contents}

List of Figures

viii

List of Tables

ix

Acknowledgements x

Preface xi

List of Abbreviations and Acronyms xii

1 The Upsurge of Interest in Health Status Measurement 1

2 An Outline of the Development of Health Status Measures 15

3 Methodology 45

4 Quality as an Issue $\quad 57$

5 The Measurement Process $\quad 71$

6 Implications for Decision-Making 90

7 Trends and Issues 102

$\begin{array}{lr}\text { Concluding Remarks } & 122\end{array}$

$\begin{array}{lr}\text { References } & 125\end{array}$

$\begin{array}{lr}\text { Index } & 137\end{array}$ 


\section{Figures}

2.1 Functional status questionnaire

2.2 Functional status report: sample

2.3 AIMS questionnaire

3.1 Functional assessments: guidelines for evaluation 50

4.1 An analytic strategy for research on the quality of mental health services

5.1 Euroqol: own health state measure 75

5.2 Standard gamble for a chronic health state preferred to death 77

5.3 Time trade-off for a chronic health state preferred to death 80

5.4 Quality-adjusted life-years added by treatment 83

7.1 A conceptual scheme for valuation in health 116 


\section{Tables}

1.1 Types of economic evaluation 3

2.1 Functional assessment instruments 20

2.2 Functional assessment measures: some examples of coverage 20

2.3 The Bush index: function levels and associated levels of well-being 25

2.4 The Bush index: symptom-problem complexes 29

2.5 Rosser's classification of illness states 31

2.6 Rosser's valuation matrix for 70 respondents 31

2.7 Generic measures: aggregate 33

$\begin{array}{ll}2.8 \text { Health profiles: an outline } & 34\end{array}$

2.9 Stages in development of two models for measuring
quality of life

2.10 Disease specific measures 37

2.11 Sample items from the Mental Health Inventory (MHI) 42

2.12 Mental instruments $\quad 42$

$\begin{array}{lll}4.1 & \text { Rheumatology standards } & 62\end{array}$

5.1 Euroqol: results of three pilot studies $\quad 88$

7.1 Frequency of usage of measurement instruments 104

7.2 Quality adjusted life-year (QALY) of competing therapies:
some tentative estimates 


\section{Acknowledgements}

I would like to thank the editors of the series, Alistair McGuire and Gavin Mooney, for their substantial contributions to the shape and contents of the book. Gavin originally suggested (over liquid refreshment in Nyhavn, Copenhagen) that I write the book, and then provided valuable comments as the book took shape. Ali was most helpful in reviewing and commenting upon an entire draft of the book.

I am very grateful to the personnel at the Swedish Institute for Health Economics for making me welcome over a number of years at their excellent facilities in Lund: a lot of the background work for the book was undertaken there. Björn Lindgren, the former director of the Institute, has my special thanks for stimulating my interest in health status measurement in the first place and then for giving me every encouragement to keep up this interest.

I would like to thank three of my former students at the Department of Economics, University of Strathclyde, for their assistance: Angela Boland, Clare Reid and Lesley Corrigan. Lesley was especially helpful during the final stages of preparation of the manuscript, including the reference list and the index. I would like also to acknowledge the financial assistance provided by the Journal of Economic Studies Fund at the University of Strathclyde.

All sins of omission and commission are, of course, my responsibility.

Permission to include the following material is gratefully acknowledged:

Figures 2.1 and 2.2: Alan Jette and the Journal of General Internal Medicine. Figure 2.3: J.B. Lippincott Company.

Figure 3.1 and Table 4.1: Clare Bombardier and the Journal of Rheumatology. Figure 4.1: Elizabeth McGlynn and Inquiry.

Figure 5.3: George Torrance and Elsevier Science Publications.

Figure 5.4: Mike Drummond.

Tables 2.3 and 2.4: Reprinted with permission from the Hospital Research and Educational Trust.

Tables 2.5 and 2.6: Claire Gudex and Paul Kind.

Table 2.9: Gordon Guyatt.

Table 2.11: John Ware.

Table 7.2: Alan Maynard. 


\section{Preface}

This book is about the development of outcome measures in health, with particular emphasis on health status and health-related quality of life measurement. It is explicitly concerned to place this development within the changing context of the health world, not least its relevance to the changing requirements of health care decision-making at all levels.

Starting with an economic framework which encompasses the requirement to match costs with outcomes, the question is addressed: why has there been such an upsurge of interest in health status measurement in handling outcomes? The present situation is placed into its historical context by showing how health status measures have developed from the early attempts at functional assessment in the 1940s and 1950s. A variety of health status and health-related quality-of-life measures are illustrated and discussed. The methodological requirements for 'sound' health status measurement are outlined, and the measurement process itself - commonly referred to as 'scaling' - is reviewed. Any reading of the burgeoning literature in this field will provide ample evidence of the pervasiveness of the attempts to define, conceptualise, and measure 'quality' as it pertains to the use of resources in the health sector and in the notion of (health-related) quality of life. Issues surrounding quality are thus given some attention. The final two chapters cover a wide range of issues surrounding health status measurement, its place in health services research, and its implications for decision-making.

RICHARD G. BROOKS 


\section{Abbreviations and Acronyms}

$\begin{array}{ll}\text { ADL } & \text { Activities of daily living } \\ \text { AIMS } & \text { Arthritis Impact Measurement Scale } \\ \text { C } & \text { Celsius } \\ \text { CS } & \text { Category scaling } \\ \text { CBA } & \text { Cost-benefit analysis } \\ \text { CEA } & \text { Cost-effectiveness analysis } \\ \text { CR } & \text { Category rating } \\ \text { CUA } & \text { Cost-utility analysis } \\ \text { DOMPS } & \text { Diseases of medical progress } \\ \text { DUHP } & \text { Duke-UNC Health Profile } \\ \text { ESR } & \text { Erythrocyte sedimentation rate } \\ \text { F } & \text { Fahrenheit } \\ \text { FDA } & \text { Food and Drug Administration } \\ \text { FLP } & \text { Functional Limitations Profile } \\ \text { FSI } & \text { Functional Status Index } \\ \text { FSQ } & \text { Functional Status Questionnaire } \\ \text { GHQ } & \text { General Health Questionnaire } \\ \text { HAQ } & \text { Health Assessment Questionnaire } \\ \text { HCFA } & \text { Health Care and Financing Administration } \\ \text { HYE } & \text { Healthy year equivalent } \\ \text { IADL } & \text { Instrumental activities of daily living } \\ \text { IHQL } & \text { Index of Health-Related Quality of Life } \\ \text { JCAH } & \text { Joint Commission on Accreditation of Hospitals } \\ \text { ME } & \text { Magnitude estimation } \\ \text { MHAQ } & \text { Modified Health Assessment Questionnaire } \\ \text { MHI } & \text { Mental Health Inventory } \\ \text { NHP } & \text { Nottingham Health Profile } \\ \text { QA } & \text { Quality assurance } \\ \text { QALY } & \text { Quality adjusted life-year } \\ \text { QWB } & \text { Quality of well-being } \\ \text { RAWP } & \text { Resource Allocation Working Party } \\ \text { RCT } & \text { Randomised control trial } \\ \text { RS } & \text { Rating scale } \\ & \end{array}$


SAVE Saved young life equivalent

SG Standard gamble

SIP Sickness Impact Profile

TA Technology assessment

TTO Time trade-off

UK United Kingdom

US(A) United States of America

VAS Visual analogue scale

WHO World Health Organisation 